\title{
FAKTOR MATERNAL DAN PELAYANAN ANTE NATAL CARE TERINTEGRASI PADA KEJADIAN PREMATURITAS DI PUSKESMAS WILAYAH KOTA PALANGKA RAYA
}

\section{Maternal Factors And Integrated Ante Natal Care Services with Prematurity Cases at Public Health Center In Region of Palangkaraya}

Legawati ${ }^{1}$ Riyanti $^{2}$ Noordiati $^{3}$

Program Studi Diploma III Kebidanan Poltekkes Kemenkes Palangka Raya JI. George Obos No.30 Palangka RayaProvinsi Kalimantan Tengah, Indonesia Korespondensi Penulis:legawatipoltekkes@gmail.com

\begin{abstract}
Premature delivery is a risk factor that causes neonatal death. Various attempts were made to reduce the neonatal mortality rate, such as integrated antenatal care. The purpose of this study is to determine maternal factors and its integrated services that affect the incidence of prematurity at Public Health Center In Region of Palangka Raya. This is a quantitative research. This study proves the bivariate analysis that the integrated Ante Natal Care, factors age maternal, parity, history of labor, employment, social, economic and distance delivery with the incidence of prematurity, while multivariate analysis proves ANC integrated, factors maternal age, occupation, parity and distance delivery to give effect to the incidence of prematurity in the city of Palangkaraya .
\end{abstract}

Keyword : Maternal Factors, Integrated ANC and Prematurity

\section{ABSTRAK}

Kelahiran Prematur merupakan faktor risiko yang menyebabkan kematian neonatal. Berbagai upaya dilakukan untuk menurunkan angka kematian neonatal, salah satunya melalui pelayanan antenatal terintegrasi.Tujuan penelitian ini untuk mengetahui faktor maternal dan pelayanan terintegrasi yang mempengaruhi kejadian prematuritas di Puskesmas Wilayah Kota Palangka Raya.Dengan menggunakan metodekuantitatif. Dengan menggunakan analisis bivariat dibuktikan bahwa Ante Natal Care terintegrasi, faktor maternal umur, paritas, riwayat persalinan, pekerjaan, sosial ekonomi dan jarak persalinan memengaruhi kejadian prematuritas, sedangkan analisis multivariat membuktikan ANC terintegrasi, faktor maternal umur, pekerjaan, paritas dan jarak persalinan memberi pengaruh terhadap kejadian prematuritas di Kota Palangka Raya.

Keyword : Faktor Maternal, ANC Terintegrasi dan Prematuritas 


\section{PENDAHULUAN}

Kematian neonatus masih merupakan permasalahan yang serius dinegaranegara berkembang. WHO (2012) mencatat kelahiran prematur di Indonesia tahun 2010 adalah 15,5 per 100.000 kelahiran hidup dan Indonesia menempati posisi ke-9 tertinggi dari 184 negara di dunia. Penyumbang utama kematian neonatal tersebut adalah Bayi Berat Lahir Rendahyang disebabkan prematuritas, infeksi, asfiksia lahir, hipotermia dan pemberian ASI yang tidak adekuat.

Kelahiran Prematur merupakan faktor risiko yang menyebabkan kematian neonatal sebanyak $50 \%$ dari seluruh kematian. Persalinan prematur dengan komplikasi adalah penyebab langsung kematian neonatal sebanyak $35 \%$ dari 3 juta kematian neonatal didunia pertahun. Infeksi Neonatal merupakan faktor risiko dominan untuk bayi lahir prematur, dimana kelahiran prematur juga merupakan penyebab kedua kematian anak dibawah lima tahun setelah pneumonia (Bergh et al., 2012).

Menurut buku Acuan Asuhan Persalinan Normal (2008) banyak cara yang dilakukan untuk mencegah kematian BBLR, beberapa penelitian menemukan bahwa salah satu faktor yang dapat memengaruhi kejadian prematuritas adalah ANC berkualitas dan terintegrasi.

Antenatal Care merupakan intervensi penting untuk menilai faktor risiko yang berhubungan dengan kehamilan, konseling dan manajemen yang akan datang. Ibu yang melakukan antenatal care 1 kali memiliki risiko melahirkan prematur 6 kali lebih tinggi dibandingkan ibu yang melakukan antenatal care 5 kali dan risiko ini akanmeningkat $21 \%$ pada ibu yang tidak pernah sama sekali melakukan prenatal care (Darmayanti et al., 2010). Perawatan kesehatan ibu sangat penting karena dapat memengaruhi kesehatan perinatal dan bayi yang akan dilahirkan.

Angka kematian ibu dan neonatal tinggi berhubungan dengan tidak adekuat dan rendahnya kualitas pelayanan kesehatan ibu termasuk pelayanan ante natal care, pertolongan persalinan dan perawatan bayi baru lahir (Dibaba et al., 2013).

Kejadian bayi lahir prematur dapat dipengaruhi oleh banyak faktor yang meliputi faktor ibu terdiri dari faktor riwayat kehamilan dan kelahiran sebelumnya, faktor demografi, dan faktor nutrisi. Faktor lain yang memengaruhi yaitu lingkungan seperti gaya hidup, racun lingkungan, bahaya pekerjaan, kekerasan dan perawatan kehamilan (antenatal care). Sementara faktor janin meliputi jenis kelamin dan faktor genetik, serta faktor lainnya yang terdiri dari faktor uterus, plasenta, farmakologi, faktor ayah dan faktor kehamilan ganda atau kembar (Yuliva et al., 2009).

Persalinan prematur merupakan masalah yang dapat dicegah dengan perawatan kehamilan yang kontinyu dan selalu memiliki kemampuan untuk mengakses pelayanan kehamilan, 
perawatan kehamilan yang berkualitas tinggi sebelum dan selama kehamilan dan juga dukungan penuh untuk menolong ibu hamil dalam mendapatkan pelayanan berkualitas apabila terjadi komplikasi (Lincetto et al., 2005). Indikator antara yang digunakan untuk menggambarkan keberhasilan program pelayanan kesehatan ibu adalah akses ibu hamil terhadap pelayanan kesehatan yang diukur dengan cakupan pelayanan antenatal ( $\mathrm{K} 1$ dan K4) Secara nasionalangka cakupan pelayanan antenatal saat ini sudah tinggi, walaupun masih ada beberapa provinsi dan kabupaten/kota belum memenuhi target/ angka pencapaian nasional. Pelayanan ANC terintegrasi atau terpadu adalah pelayanan antenatal yang diintegrasikan dengan pelayanan program lain yang berkaitan dengan gizi, malaria dan kecacingan. Pelayanan antenatal terintegrasi merupakan upaya yang dilakukan untuk meningkatkan derajat kesehatan ibu dan janin agar dapat melalui kehamilan persalinan dengan aman dan selamat.

\section{METODOLOGI PENELITIAN}

Jenis penelitian ini adalah penelitian deskriptif observasional, dengan rancangan cohortProspective Study Hal ini dilakukan untuk melihat gambaran suatu populasi pada dilakukan deteksi secara dini faktor predisposisi pada ibu hamil setelah diberikan perlakuan ANC terintegrasi. Pada penelitian ini pengukuran dilakukan dalam waktu bersamaan antara Faktor Maternal dan ANC terintegrasi (variabel bebas) sedangkan kejadian Prematuritas (variabel terikat) diikuti ketika ibu melahirkan.

Populasi penelitian ibu hamil di puskesmas Pahandut dan Kalampangan yang ada di wilayah kota Palangka Raya, menjadi subyek penelitian adalah ibu hamil trimester III. Dengan sampel 106 orang ibu hamil. Cara pengambilansampel pada penelitian ini dilakukan dengan cara purposive sampling.

\section{Hasil}

Penelitian ini dilakukan pada ibu hamil trimester III yang berkunjung di Puskesmas Pahandut dan Kalampangan Kota Palangka Raya yang memenuhi kriteria inklusi dan ekslusi berjumlah 106 orang. Hasil analisis bivariat menunjukkan pengaruh antara variabel faktor maternal dan ANC terintegrasi dengan kejadian prematur sebagai berikut: 


\section{Tabel 1 Analisis bivariabel}

\begin{tabular}{llllllll}
\hline \multirow{2}{*}{ Variabel } & \multicolumn{9}{c}{ Prematuritas } & & & \\
& & Ya & \multicolumn{2}{c}{ Tidak } & $\boldsymbol{x}^{2}$ & $\mathbf{R R}$ & $\mathbf{9 5 \%}$ \\
& $\mathbf{N}$ & $\mathbf{n}$ & $\mathbf{\%}$ & & & $\mathbf{C l}$ \\
\hline ANC Terintegrasi & & & & & & & \\
- Ya $\quad$ Tidak & 4 & 75, & 1 & 24, & 19, & 2,2 & 1,48 \\
& 4 & 9 & 4 & 1 & 3 & 7 & - \\
& 1 & 33, & 3 & 66, & & & 3,48 \\
& 6 & 3 & 2 & 7 & & &
\end{tabular}

Umur

$\begin{array}{llllllll}-\quad 20-35 \text { thn } & 4 & 75, & 1 & 24, & 19, & 2,2 & 1,48 \\ -\quad>35 \text { thn } & 4 & 9 & 4 & 1 & 3 & 7 & - \\ & 1 & 33, & 3 & 66, & & & 3,48 \\ & 6 & 3 & 2 & 7 & & & \end{array}$

Paritas

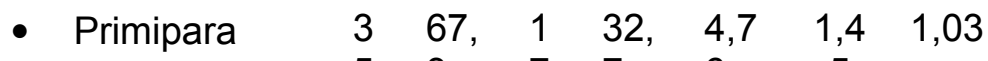

$\begin{array}{llllllll}\text { - Multipara } & 5 & 3 & 7 & 7 & 6 & 5 & - \\ & 2 & 46, & 2 & 53, & & & 2,05\end{array}$

Riwayat

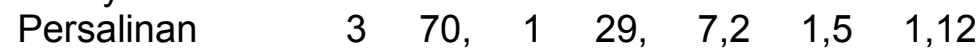

Prematur

- Ya

- Tidak

$\begin{array}{lllllll}4 & 8 & 4 & 2 & 3 & 8 & -\end{array}$

Pekerjaan

$244,355, \quad 2,21$

- Bekerja

$\begin{array}{llll}6 & 8 & 2 & 2\end{array}$

- Tidak Bekerja

$\begin{array}{lllllll}4 & 71 & 1 & 29 & 12, & 1,9 & 1,27\end{array}$

$436,863,655$

$\begin{array}{lllll}1 & 4 & 2 & 6 & 2,97\end{array}$

Sosial Ekonomi

$\begin{array}{lllllll}\text { - Rendah } 3 & 70, & 1 & 29, & 7,2 & 1,5 & 1,12\end{array}$

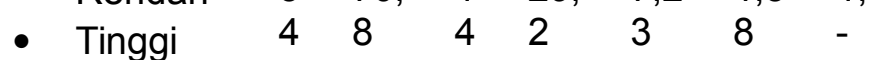

Jarak Kehamilan $2 \quad 44,3 \quad 55, \quad 2,21$

- $<2$ thn $6 \quad 8 \quad 2 \quad 2$

- $\geq 2$ thn $11,2,0$

$\begin{array}{lllllll}4 & 69 & 1 & 30 & 6 & 1 & 1,22 \\ 3 & 3 & 9 & 70 & & & - \\ 1 & & 2 & & & & 3,01 \\ 7 & & 9 & & & & \end{array}$


Legawati, Riyanti dan Noordiati

Hasil analisis multivariat dengan menggunakan regresi logistik ditunjukan tabel 2 dibawah ini:

Tabel 2Analisa Logistic Regression: Pengaruh ANC Terintegrasi terhadapPrematuritas Variabel dengan mengontrol variabel luar

\begin{tabular}{|c|c|c|c|c|}
\hline Variabel & $\begin{array}{c}\text { Model } \\
1 \\
\text { OR } \\
95 \% \\
\text { Cl }\end{array}$ & $\begin{array}{c}\text { Model } \\
2 \\
\text { OR } \\
95 \% \\
\text { Cl } \\
\end{array}$ & $\begin{array}{c}\text { Model } \\
3 \\
\text { OR } \\
95 \% \\
\mathrm{Cl} \\
\end{array}$ & $\begin{array}{c}\text { Model } \\
4 \\
\text { OR } \\
95 \% \\
\mathrm{Cl} \\
\end{array}$ \\
\hline \multicolumn{5}{|l|}{ ANC Terintegrasi } \\
\hline $\begin{array}{l}\text { - } Y a \\
\text { - } \quad \text { Tidak }\end{array}$ & $\begin{array}{c}6,29 \\
(2,69- \\
14,7) \\
1\end{array}$ & $\begin{array}{c}6,53 \\
(2,71- \\
18,04) \\
1\end{array}$ & $\begin{array}{c}7,24 \\
(2,91- \\
18,04) \\
1\end{array}$ & $\begin{array}{c}10,8 \\
(3,7- \\
31,3) \\
1\end{array}$ \\
\hline \multicolumn{5}{|l|}{ Paritas } \\
\hline $\begin{array}{l}\text { - } \text { Primipara } \\
\text { - } \text { Multipara }\end{array}$ & & $\begin{array}{c}2,57 \\
(1,07- \\
6,19) \\
1\end{array}$ & & \\
\hline \multicolumn{5}{|l|}{ Umur } \\
\hline $\begin{array}{l}\text { - } 20-35 \text { thn } \\
\text { - } \quad>35 \text { thn }\end{array}$ & & & $\begin{array}{c}3,68 \\
(1,46- \\
9,29) \\
1\end{array}$ & \\
\hline $\begin{array}{c}\text { Pekerjaan } \\
\text { - Bekerja } \\
\text { - } \quad \text { Tidak } \\
\text { Bekerja }\end{array}$ & & & & $\begin{array}{c}7,89 \\
(2,7- \\
23,1) \\
1\end{array}$ \\
\hline $\begin{array}{c}\text { Jarak Kehamilan } \\
-\quad<2 \text { thn } \\
-\quad \geq 2 \text { thn }\end{array}$ & & & & $\begin{array}{c}2,57 \\
(1,07- \\
6,19) \\
1\end{array}$ \\
\hline$N$ & 106 & 106 & 106 & 106 \\
\hline $\mathrm{R}^{2}$ & 0,14 & 0,17 & 0,19 & 0,26 \\
\hline Deviance & 125,2 & 120,6 & 117 & 107,4 \\
\hline
\end{tabular}


Faktor Maternal Dan Pelayanan Ante Natal Care Terintegrasi Pada Kejadian Prematuritas Di Puskesmas Wilayah kota Palangka Raya

Berdasarkan hasil analisis multivariabel dengan regresi logistikdengan melakukan permodelan, terdapat hubungan yang bermakna antara ANC Terintegrasi dengan Prematuritas dengan melakukan kontrol pada beberapa variabel lain.Pemodelan dalam logistic regression menampilkan nilai OR dan Confidence Interval (Cl) 95\%. Nilai -2 log likelihood atau deviance digunakan untuk membandingkan perbedaan regresi model 1 dengan model regresi lainnya. Perbedaan bermakna secara statistik jika model regresi yang lain berbeda dengan regresi model 1 , berarti variabel tambahan lain selain variabel bebas mempunyai peluang mempengaruhi variabel terikat dan berpeluang merubah nilai OR pada variabel bebasnya. R2 yaitu melihatseberapa jauh seluruh variabel dalam setiap model memprediksi proporsi bayi prematur.

\section{Pembahasan}

Hasil analisis bivariabel dan multivariabel menunjukkan hubungan yang bermakna antara ANC Terintegrasi dengan kejadian prematuritas. Penelitian ini didukung oleh Utami dan Irwanti (2014) menemukan terdapat hubungan yang bermakna dan signifikan antara Kunjungan ANC pada kejadian Prematuritas. Menurut Requajo dkk (2013), kehamilan dan persalinan merupakan suatu periode kritis ketika seorang wanita dapat melalui berbagai mekanisme dengan intervensi yang bertujuan untuk mengurangi resiko dari kelahiran prematur dan meningkatkan kesehatan dirinya dan kesehatan dari janin. Mekanisme ini termasuk berbagai layanan yang diberikan selama antenatal untuk semua ibu hamil dan ibu yang berisiko tinggi melahirkan prematur, layanan yang disediakan untuk mengelola persalinan prematur, dan penolong yang profesional dan kebijakan yang mendukung dengan tujuan meningkatkan keselamatan ibu dan akses dasar untuk peduli sebelum, selama dan setelah kehamilan. Negara harus menjamin akses yang adil. Bukti baru menunjukkan perlu dialokasikan sumber daya untuk alat-alat baru, skrining, diagnostik, dan intervensi lainnya yang ditujukan untuk menyelamatkan ibu dan bayi di semua negara di dunia. Sebuah penelitian di Amerika Serikat menunjukkan bahwa wanita yang tidak mendapatkan perawatan prenatal mengalami peningkatan risiko melahirkan prematur. Perawatan prenatal memiliki dampak besar bagi wanita yang kurang beruntung secara sosial, karena risiko secara keseluruhan tinggi untuk melahirkan bayi berat badan lahir rendah. Dari penelitian ini, tampak manfaat layanan antenatal dimodifikasi oleh situasi sosial. Menurut Smith dkk (2009) pentingnya perawatan prenatal yang rutin untuk 
mendeteksi perempuan dengan risiko tinggi melahirkan prematur dan melakukan monitoring serta intervensi yang intensif.

Hasil analisis bivariabel dan multivariabel juga menunjukkan hubungan yang bermakna antara paritas dengan kejadian Prematuritas. Penelitian ini didukung oleh Utami dan Irwanti (2014) menemukan bahwa terdapat hubungan yang bermakna dan signifikan antara paritas pada kejadian Prematuritas. Penelitian ini juga menemukan bahwa paritas merupakan faktor yang berpengaruh terhadap perawatan antenatal komprehensif, pelayanan persalinan yang berkualitas, pelayanan obstetrik darurat.

Pelayanan antenatal harus mencakup skrining dan pengelolaan wanita yang berisiko tinggi melahirkan prematur, skrining dan pengobatan infeksi, dan dukungan gizi dan konseling. Petugas kesehatan perlu dilatih dan dilengkapi peralatan untuk memberikan pelayanan yang efektif dan manajemen klinis tepat waktu bagi perempuan dalam persalinan prematur yang bertujuan meningkatkan peluang kelangsungan hidup bagi bayi. Paritas multipara merupakan faktor maternal yang dapat meningkatkan kejadian prematuritas. Hal ini sesuai pula dengan teori yang menyatakan bahwa terdapat kecenderungan kesehatan ibu yang berparitas rendah lebih baik dibandingkan dengan ibu yang berparitas tinggi.
Hasil uji statistik membuktikan bahwa hubungan yang bermakna antara umur dengan kejadian Prematuritas. Penelitian ini didukung oleh Utami dan Irwanti (2014) menemukan bahwa terdapat hubungan yang bermakna dan signifikan antara umur ibu pada kejadian Prematuritas. Dimana Ibu yang berumur $<25$ thn dan $>35$ tahun mengalami peningkatan kejadian prematuritas. Hal ini sesuai dengan hasil penelitian yang menyatakan bahwa usia ibu <16 thn dan > 35 thn meningkatkan risiko kejadian prematuritas. Penelitian di Rumah Sakit Tugurejo Semarang tahun 2012 menunjukkan angka kejadian prematur pada ibu kelompok risiko usia kurang dari 20 tahun sebesar $10.98 \%$ dan usia lebih dari 35 tahun sebesar 16,46\%.

Proses kehamilan dan kelahiran pada usia remaja (< 20 tahun) turut berkontribusi dalam meningkatkan angka kematian perinatal di Indonesia. Ibu hamil usia remaja sering mengalami komplikasi kehamilan yang buruk seperti persalinan prematur, berat bayi lahir rendah (BBLR) dan kematian perinatal. Ibu remaja mempunyai peluang 3,88 kali untuk melahirkan bayi premature dibanding ibu bukan remaja. Hasil analisa data Riskesdas Tahun 2013 menunjukkan bahwa ibu dengan umur lebih dari 34 tahun mempunyai peluang mengalami kejadian kelahiran prematur 2,889 kali. Organ reproduksi pada usia remaja masih belum siap untuk menerima hasil 
Faktor Maternal Dan Pelayanan Ante Natal Care Terintegrasi Pada Kejadian Prematuritas Di Puskesmas Wilayah kota Palangka Raya

konsepsi dan peningkatan kebutuhan nutrisi selama kehamilan dapat membahayakan pertumbuhan remaja dengan potensial yang sama terhadap fetus. Berat bayi lahir yang rendah dan penyulit selama kehamilan dan persalinan dapatterjadi akibat tidak adekuatnya nutrisi, karena kebutuhan nutrisi masih dibutuhkan untuk pertumbuhan fisik dari remaja sehingga terjadi kompetisi dengan kebutuhan untuk janin. Organ reproduksi pada wanita usia lebih dari 35 tahun telah mengalami kemunduran fungsi untuk menerima hasil konsepsi sehingga berpeluang mendapatkan komplikasi lebih tinggi dibandingkan usia reproduksi sehat.

Hasil penelitian ini juga membuktikan bahwa pekerjaan memiliki pengaruh positif terhadap kejadian prematuritas. Ibu yang bekerja 13,19 kali berpeluang mengalami persalinan prematur dibandingkan yang tidak bekerja. Penelitian Latifah dan Anggraeni (2011) didapatkan jenis pekerjaan ibu yang melahirkan prematur terbanyak adalah IRT yaitu 45 orang (75\%). Sedangkan responden yang bekerja sebagai siswa dan buruh masing-masing $18,3 \%$ dan $6,7 \%$. Ibu remaja hamil juga lebih sering tidak bekerja (37.6\%) daripada ibu hamil dewasa (16.9\%) dengan $p<0,001 .{ }^{18}$ Wanita yang bekerja antara 10 p.m dan 7 a.m. setiap harinya akan mendapatkan resiko kelahiran prematur. Sebagai contoh wanita yang kerja secara shfit malam hari dalam tiga bulan pertama akan memiliki potensi $50 \%$ melahirkan secara prematur. Aktifitas pekerjaan malam akan merubah uterus aktifitas uterus berjalan tidak pada semestinya. ${ }^{19}$ Pekerjaan dapat menyebabkan kelelahan fisik dan psikologi ibu sehingga fungsi tubuh dapat terganggu.

Analisis membuktikan adanya hubungan yang bermakna antara jarak kehamilan dengan kejadian Prematuritas. Dimana kejadian prematuritas pada ibu dengan jarak $<2$ thn memiliki jumlah lebih sedikit dibandingkan dengan ibu yang memiliki jarak kehamilan $\geq 2$ tahun. Sebuah penelitian di California menjelaskan bahwa jarak melahirkan satu anak ke anak berikutnya ternyata berhubungan dengan risiko kelahiran prematur.Jika ibu mengandung kembali dengan rentang waktu kurang dari 6 bulan sejak melahirkan risiko kelahiran prematur adalah sebesar $70 \%$.Jika jarak kehamilan dari persalinan sebelumnya adalah antara 6 hingga 11 bulan, maka risiko melahirkan prematur menjadi $20 \%$. Sedangkan saat kehamilan berlangsung dengan jarak 18 hingga 23 bulan setelah melahirkan, maka tidak ada risiko melahirkan prematur.

Hasil penelitian ini membuktikan bahwa tubuh seorang perempuan membutuhkan masa pemulihan setelah melahirkan.Secara emosi pun, ibu menjadi lebih tenang menerima kehadiran bayi 
Faktor Maternal Dan Pelayanan Ante Natal Care Terintegrasi Pada Kejadian Prematuritas Di Puskesmas Wilayah kota Palangka Raya

yang dikandungnya, karena kelelahan fisik

yang telah mereda setelah kelahiran 
sebelumnya.Jika jarak kehamilan terlalu dekat dengan kehamilan sebelumnya, maka akan banyak resiko yang menimpa baik ibu maupun janinnya. Rahim yang masih belum pulih benar akibat persalinan sebelumnya belum bisa memaksimalkan pembentukan cadangan makanan bagi janin dan untuk ibu sendiri. Akibatnya bayi akan terlahir dengan berat badan rendah, kekurangan zat gizi sehingga bayi menjadi tidak sehat. Selain itu bayi juga rentan terhadap kelainan plasenta, pertumbuhan yang terhadap dan penelitian terakhir munjukkan bayi dengan jarak kehamilan terlalu dekat rentan terkena autisme. Semua ini tentunya akan mengurangi kualitas dari bayi itu sendiri. Bagi ibu sendiri meningkatkan resiko terkena anemia akut. Ibu hamil yang terkena anemia akut akan meningkatkan resiko terhadap perdarahan, komplikasi kehamilan, bayi terlahir prematur, resiko perdarahan saat persalinan dan resiko terburuk yaitu_keguguran.

\section{Kesimpulan}

Dari hasil penelitian dapat disimpulkan bahwa ANC terintegrasi, faktor maternal umur, paritas, pekerjaan, dan jarak kehamilan memengaruhi kejadian prematuritas.

\section{Saran}

Semua ibu hamil dapat melakukan kunjungan ante natal care secara teratur untuk mendapatkan pelayanan ANC terintegrasi. Tenaga kesehatan dapat melaksanakan ANC Terintegrasi padasemua tatananlayanan kebidanan.Pengampu kebijakan agar dapat melengkapi sarana dan prasarana pendukung pelaksanaan ANC Terintegrasi.

\section{DAFTAR PUSTAKA}

WHO.Born Too Soon: The Global Action Report on Preterm Birth,Geneva: WHO. 2012.

Departemen Kesehatan RI. Buku Saku Pelayanan Kesehatan Neonatal Esensial. Jakarta.Depekes RI. 2010

Bergh MA, Manu R, DavyK, RoyenVE, AsareQG, Williams AJK, Dedzo McD, Twumasi A andNangbeifubahA. Translating Research Findings Into Practice-The Implementation og Kangarro Mother Care in Ghana. Implementation Science 75 (7): 2012

JNPKR. Buku Acuan Asuhan Persalinan Normal. Jakarta: 2008

Darmayanti, Siswanti AW dan DettyST. Pengaruh Kenaikan Berat Badan Rata - Rata Per Minggu Pada Kehamilan Trimester II dan III Terhadap Risiko Berat Bayi Lahir Rendah. Berita Kedokteran Masyarakat No. 01 Vol 26 (1-53). FK UGM: Yogyakarta.2010

Dibaba Y, Fantahun M and Hindin MJ. The effects of pregnancy intention on the use of antenatal care services: systematic review and meta-analysis 10(50); 2013.

Yuliva, Ismail D dan Rumekti D. Hubungan Status Pekerjaan Ibu dengan Berat Lahir Bayi Di RSUP Dr. M. Djamil Padang. Berita Kedokteran Masyarakat No. 02 Vol 25 (51-108). FK UGM: Yogyakarta.2009 
Legawati, Riyanti dan Noordiati

LincettoO, AnohSM, Gomez $\mathrm{P}$ and Munjanja S. Antenatal Care. 
Opputunities for Africa's Newborn, JHPIEGO; 2013

Departemen Kesehatan RI. Buku Kesehatan Ibu dan Anak. Jakarta; Depkes RI. 2009

Utami EE, Ernawati S dan Irwanti W. Hubungan Frekuensi Kunjungan ANC dengan Kejadian Prematur. Jurnal Ners dan Kebidanan Indonesia Vol 2: (1). 2014

Requejo J, Merialdi M, Althabe F,Kelles M, Katz J, and Menon R. Born Too Soon: Care During Pregnancy And Childbirth To Reduce Preterm Deliveries And Improve Health Outcomes Of The Preterm Baby. Journal Reproductive Health 10 (Suppl 1):2013 Tersedia http://www.reproductive-healthjournal.com. Diakses tanggal 12 September 2016

Greenberg RS. The Impact Of Prenatal Care In Different Social Groups. AJOG Vol 145 (7): 797-80.1982. Tersedia di www.ncbi.nlm.nih.gov/pubmed/668229

0. Diakses tanggal 10 September 2016

Smith GCS, Emily JS, Jennifer AC, David AA,Alan DC, and J Michael C.Early Pregnancy Levels of PregnancyAssociated Plasma Protein A and the Risk of Intrauterine Growth Restriction, Premature Birth, Preeclampsia, and Stillbirth.2009. Tersedia di http://press.endocrine.org. Diakses tanggal 10 September 2016.

Sulistiani D dan Berliana SM. Faktor-faktor yang Memengaruhi Kelahiran Prematur di Indonesia Analisis Data Riskesdas 2013. E-Journal Widya
Kesehatan Dan Lingkungan Vol 1(2); 2016.

Notoatmodjo Soekidjo, Promosi Kesehatan Teori dan Aplikasi, Edisi revisi. Jakarta : Rineka Cipta.2010.

Krisnadi . Prematuritas. Bandung : Refika Aditama. 2009

Prawirohardjo Sarwono. IImu kebidanan. Jakarta: Yayasan Bina Pustaka Sarwono Prawirohardjo.2010

Latifah L dan Anggraeni DM. Hubungan Kehamilan Pada Usia Remaja Dengan Kejadian Prematuritas, Berat Bayi Lahir Rendah Dan Asfiksia. Jurusan Kesehatan Masyarakat Fakultas Kedokteran Dan IImu-IImu Kesehatan Universitas Jenderal Soedirman.2011.Tersedia di http://kesmas.unsoed.ac.id. Diakses tanggal 5 Januari 2016.

Pompeii LA, Savitz, DA, EvensonKR. Rogers B; and McMahon MMD. Physical Exertion at Work and the Risk of Preterm Delivery and Small-forGestational- Age Birth. Journal of Obstetrics\& Gynecology. Vol 106(6). 2005

BZ Shachar,JA Mayo,DJ Lyell,RJ Baer,LL Jeliffe-Pawlowski,DK Stevenson,GM Shaw. Interpregnancy interval after live birth or pregnancy termination and estimated risk of preterm birth: a retrospective cohort study. Journal of BJOG.Juli 2016.Tersedia dihttp://onlinelibrary.wiley.com/doi/10.1 111/1471-0528.14165. Diakses tanggal 13 September 2016 